\title{
Penerapan Metode Eksperimen dapat Meningkatkan Aktivitas dan Hasil Belajar IPA Siswa Sekolah Dasar
}

\author{
Suryani ${ }^{1}$ \\ SDN. No. 028/XI Tanjung, Kecamatan Hamparan Rawang, Kota Sungai Penuh, Provinsi Jambi ${ }^{1}$ \\ E-mail: suryani10111969@gmail.com
}

\begin{abstract}
This study aims to improve the learning activity and learning outcomes of fifth grade student's SDN. No. 052/XI Ulu Air year 2016/2017 on natural science subjects, especially on the material properties of light through the application of experiment methods. The study was conducted from January to May 2017. The study involved 18 students of fifth grade student's SDN. No. 052/XI Ulu Air year 2016/2017. The study was conducted in two cycles and each cycle consisted of four activities namely planning, implementation, observation, and reflection. Data of learning activity was collected through observation and data of learning outcome was collected through the test. The data that have been collected is analyzed by descriptive analysis and simple statistical test. The results showed that student learning activities improved. The results also showed that the average score of students increased from 52,8 on before action applied to 65,3 in Cycle I and increased to 77,5 in Cycle II. Percentage mastery learning students also experienced an increase from 50,0\% in pratindakan to 72,2\% in Cycle I and increased to 88,9\% in Cycle II. Thus, the experimental method can improve the learning activity and learning outcomes of fifth grade student's SDN. No. 052/XI Ulu Air year 2016/2017 on natural science subjects, especially on the material properties of light.
\end{abstract}

Keywords: elementary school, experiment method, learning activity, learning outcome, science

\section{PENDAHULUAN}

Belajar berperan penting dalam pembentukan kualitas seorang individu. Sugiyono dan Hariyanto (2011) mengartikan belajar sebagai sebuah aktivitas untuk memperoleh pengetahuan, meningkatkan keterampilan, memperbaiki perilaku/sikap, dan mengukuhkan kepribadian. Salah satu mata pelajaran yang harus dipelajari oleh siswa sejak Sekolah Dasar adalah mata pelajaran Ilmu Pengetahuan Alam (IPA). Mata pelajaran IPA mengajarkan siswa mengenai pengetahuan yang rasional dan objektif tentang alam semesta dengan segala isinya. Pembelajaran IPA di Sekolah Dasar merupakan langkah awal dalam menanamkan pengetahuan, keterampilan, dan sikap yang ilmiah pada siswa.

Hasil dari proses belajar dikenal dengan istilah hasil belajar. Pengukuran dan penilaian hasil belajar pada siswa sebagai bentuk evaluasi untuk melihat capaian pembelajaran yang telah dilakukan. Hal ini dapat terjadi karena siswa merupakan subjek utama untuk menilai baik atau buruknya suatu proses pembelajaran (Irham dan Wiyani, 2013). Oleh karenanya, guru perlu melakukan pengukuran dan penilaian hasil belajar pada siswa sebagai bentuk evaluasi untuk melihat capaian pembelajaran yang telah dilakukan.
Guru mencoba mengukur dan menilai hasil belajar pada siswa kelas V di SDN. No. 052/XI Ulu Air tahun pelajaran 2016/2017. Hasil pengukuran dan penilaian menunjukkan bahwa hasil belajar siswa pada pembelajaran IPA masih rendah yang ditandai dengan perolehan hasil belajar siswa yang belum memenuhi Kriteria Ketuntasan Minimum (KKM) kompetensi dasar untuk mata pelajaran IPA yaitu sebesar 60,00. Hasil tes penjajakan juga memperlihatkan bahwa skor yang diperoleh siswa berada pada rentang 20,0 (skor terendah) sampai dengan 75,0 (skor tertinggi) dengan nilai rata-rata sebesar 52,80. Apabila nilai yang diperoleh setiap siswa dibandingkan dengan KKM kompetensi dasar maka diperoleh hasil bahwa hanya separuh siswa yang memenuhi KKM kompetensi dasar. Masalah ini perlu dipecahkan karena dapat menghambat tercapainya tujuan pembelajaran.

Langkah awal untuk memecahkan masalah rendahnya hasil belajar siswa pada mata pelajaran IPA adalah dengan cara menganalisis penyebab dari munculnya masalah tersebut. Hasil analisis menunjukkan bahwa pelaksanaan pembelajaran masih berpusat pada guru dan cenderung kurang melibatkan siswa secara aktif. Guru juga belum pernah menerapkan metode eksperimen. Guru hanya menerangkan pelajaran dan melakukan tanya jawab. Untuk materi pelajaran yang membutuhkan pembuktian yang 
dapat dilakukan siswa, guru hanya menerangkan gambar-gambar yang ada pada buku pelajaran. Sebagian besar materi yang dipelajari pada mata pelajaran IPA bersifat abstrak sehingga kurang tepat jika diajarkan hanya dengan menggunakan metode ceramah dan tanya jawab. Akibatnya, siswa mengalami kesulitan dalam memahami materi yang diajarkan. Penggunaan metode pembelajaran yang kurang tepat tidak hanya berdampak pada hasil belajar tetapi juga berdampak pada aktivitas belajar siswa selama kegiatan pembelajaran. Hasil pengamatan menunjukkan bahwa sebagian besar siswa terlihat kurang antusias dalam mengikuti kegiatan pembelajaran, tidak menyimak penjelasan guru, melamun, menguap karena mengantuk, mengobrol dengan teman sebangkunya, serta mencoret buku catatan.

Hasil analisis menunjukkan bahwa penyebab utama dari rendahnya aktivitas dan hasil belajar siswa adalah penggunaan metode pembelajaran yang kurang tepat. Salah satu cara yang dapat dilakukan untuk mengatasi masalah tersebut adalah perbaikan metode pembelajaran. Menurut Irham dan Wiyani (2013), ada banyak jenis metode yang dapat digunakan dalam kegiatan pembelajaran, diantaranya adalah ceramah, latihan, diskusi dan tanya jawab, karyawisata, demonstrasi, sosiodrama dan bermain peran, eksperimen, dan proyek. Guru dapat memilih metode yang dipandang tepat dengan materi yang disampaikan dalam pembelajaran.

Materi pelajaran yang dibahas dalam penelitian ini adalah sifat-sifat cahaya. Setelah mengikuti kegiatan pembelajaran, siswa diharapkan dapat men-deskripsikan sifat-sifat caaya. Hasil kajian terhadap penelitianpenelitian terdahulu menyebutkan bahwa metode yang dapat digunakan untuk meningkatkan hasil belajar siswa pada mata pelajaran IPA, khususnya pada materi sifat-sifat cahaya adalah metode demonstrasi (Budiono, 2011; Novera 2012; Andriyanto, Mokoginta, dan Saleh, 2013). Budiono (2011) telah membuktikan bahwa metode demonstrasi dapat meningkatkan kemampuan belajar sifat-sifat cahaya pada siswa kelas V SD Negeri 1 Mojo Andong Boyolali Tahun Pelajaran 2010/2011. Novera (2012) juga telah membuktikan bahwa metode demonstrasi dapat meningkatkan kemampuan mengenal sifat cahaya bagi anak tuna rungu di SLB Negeri Ampek Angkek. Hasil ini juga diperkuat oleh temuan dari Andriyanto, Mokoginta, dan Saleh (2013) bahwa metode demonstrasi dapat meningkatkan hasil belajar siswa di kelas V SDN 5 Telaga Kabupaten Gorontalo tentang sifat-sifat cahaya.

Peningkatan hasil belajar siswa pada mata pelajaran IPA, khususnya pada materi sifat-sifat cahaya juga dapat dilakukan dengan menggunakan metode eksperimen. Metode eksperimen memiliki cara kerja yang hampir mirip dengan metode demonstrasi. Sugihartono dkk. (2007) mengartikan metode eksperimen sebagai metode pembelajaran yang dilakukan guru dalam bentuk pemberian kesempatan kepada siswa untuk melakukan sebuah proses atau percobaan. Metode ini cocok diterapkan pada mata pelajaran IPA. Metode ini memberikan aktivitas dan pengalaman belajar secara nyata dan terencana pada siswa (Irham dan Wiyani, 2013). Beberapa peneliti telah menggunakan metode eksperimen untuk mengatasi masalah rendahnya hasil belajar IPA di sekolahnya masing-masing. Penelitian yang dilakukan oleh Saputra (2013); Basonggo, Tangkas, dan Said, (2014); Yesnain, Ratman, dan Gagaramusu (2015); Munawar (2016); dan juga Suarni, Haeruddin, dan Dewi (2016) telah membuktikan bahwa metode eksperimen berhasil meningkatkan hasil belajar siswa kelas V Sekolah dasar pada mata pelajaran IPA, khususnya pada materi sifat-sifat cahaya.

Berdasarkan pemaparan tersebut, metode yang dinilai efektif untuk mengatasi masalah rendahnya aktivitas dan hasil belajar siswa kelas V SDN. No. 052/XI Ulu Air Tahun 2016/2017 pada mata pelajaran IPA, khususnya pada materi sifat-sifat cahaya adalah metode eksperimen. Alasan inilah yang mendorong guru untuk melakukan penelitian tindakan kelas yang berjudul "Penerapan Metode Eksperimen untuk Meningkatkan Aktivitas dan Hasil Belajar IPA Mengenai Sifat-Sifat Cahaya pada Siswa Kelas V SDN. N0. 052/XI Ulu Air Tahun 2016/2017”.

Penelitian ini bertujuan untuk meningkatkan aktivitas dan hasil belajar IPA mengenai sifat-sifat cahaya melalui penerapan metode eksperimen pada siswa Kelas V SDN. No. 052/XI Ulu Air tahun 2016/2017. Hasil penelitian ini diharapkan dapat memperluas pengetahuan tentang manfaat dari metode eksperimen dalam pembelajaran khususnya pada mata pelajaran IPA. Hasil penelitian ini diharapkan juga dapat menjadi alternatif bagi guru dalam meningkatkan aktivitas dan hasil belajar siswa dalam mata pelajaran IPA. Penelitian ini diharapkan juga bermanfaat bagi siswa. Penggunaan metode eksperimen 
diharapkan dapat memudahkan siswa dalam memahami materi pelajaran IPA yang pada akhirnya juga dapat mendorong peningkatan aktivitas dan hasil belajar siswa. Hasil penelitian ini diharapkan juga bermanfaat bagi sekolah yakni diharapkan dapat menjadi dasar dalam pengambilan kebijakan untuk meningkatkan kualitas pembelajaran di sekolah.

\section{METODE PENELITIAN}

Penelitian ini merupakan Penelitian Tindakan Kelas. Penelitian dilakukan di SDN. No. 052/XI Ulu Air, Kecamatan Kumun Debai, Kota Sungai Penuh, Provinsi Jambi. Kegiatan penelitian terdiri atas penyusunan proposal penelitian, pelaksanaan penelitian, dan penyusunan laporan penelitian. Waktu yang dibutuhkan untuk menyelesaikan laporan ini adalah 5 (lima) bulan. Kegiatan penelitian dimulai dari bulan Januari sampai dengan bulan Mei tahun 2017.

Subjek dalam penelitian ini adalah siswa kelas V Semester Genap tahun pelajaran 2016/2017 di SDN. No. 052/XI Ulu Air, Kecamatan Kumun Debai, Kota Sungai Penuh, Provinsi Jambi. Jumlah subjek yang terlibat dalam penelitian ini adalah 18 orang siswa. Selanjutnya, objek dalam penelitian ini adalah meningkatan aktivitas dan hasil belajar siswa kelas V SDN. No. 052/XI Ulu Air tahun 2016/2017 pada mata pelajaran IPA, khususnya pada materi sifat-sifat cahaya.

Penelitian tindakan kelas ini dilaksanakan dalam dua siklus yaitu siklus I dan siklus II. Siklus I dilakukan sebanyak tiga kali pertemuan, sedangkan siklus II dilakukan sebanyak dua kali pertemuan. Masing-masing siklus terdiri atas empat kegiatan, yaitu perencanaan, pelaksanakan, pengamatan, dan refleksi.

Data yang dikumpulkan dalam penelitian ini berupa data primer yaitu aktivitas belajar dan hasil belajar. Data aktivitas belajar dikumpulkan dengan cara pengamatan atau observasi. Pengamatan atau observasi merupakan salah satu bertujuan untuk mengumpulkan data, referensi, peristiwa, tindakan, dan proses yang sedang dilakukan dalam penelitian. Pengamatan atau observasi yang dilakukan dalam penelitian tindakan kelas ini berupa kegiatan pengamatan terhadap aktivitas belajar siswa selama kegiatan pembelajaran berlangsung. Untuk memudahkan pencatatan, guru menyiapkan lembar observasi. Aspek yang diamati terdiri atas siswa menyimak penjelasan yang disampaikan oleh guru; siswa menyiapkan alat dan bahan yang dibutuhkan untuk melakukan kegiatan percobaan; siswa bekerja bersama dengan siswa lain dalam sebuah kelompok; siswa membaca prosedur untuk melakukan kegiatan percobaan; siswa melakukan kegiatan percobaan sesuai dengan prosedur percobaan; siswa menuliskan hasil percobaan; siswa membersihkan kembali alat dan bahan yang digunakan dalam kegiatan percobaan; siswa mempresentasikan hasil percobaan di depan kelas; siswa membuat kesimpulan; siswa mengajukan pertanyaan pada guru atau siswa lain; siswa menjawab pertanyaan dari guru atau siswa lain; dan siswa mengikuti kegiatan pembelajaran dengan antusias.

Selanjutnya, data hasil belajar dikumpulkan dengan cara tes. Tes dilakukan dengan cara memberikan serangkaian tugas yang harus dikerjakan oleh siswa atau sekelompok siswa. Selanjutnya, guru melakukan penilaian terhadap hasil tes tersebut. Penilaian dilakukan dengan cara membandingkan hasil tes dengan standar yang telah ditetapkan. Dalam penelitian ini, standar yang digunakan adalah Kriteria Ketuntasan Minimum (KKM) mata pelajaran IPA khususnya kompetensi dasar mendeskripsikan sifat-sifat cahaya yaitu 60,0. Tes dilakukan pada akhir siklus.

Analis data diperlukan untuk mengetahui efektifitas dan tingkat keberhasilan suatu tindakan. Data aktivitas belajar dianalisis secara deskriptif. Selanjutnya, data hasil belajar siswa diukur berdasarkan nilai rata-rata siswa dan ketuntasan belajar. Penghitungan nilai rata-rata menggunakan rumus sebagai berikut:

$$
\text { Nilai rata-rata }=\frac{\sum \text { Nilai Siswa }}{\text { Jumlah siswa }} \times 100
$$

Ketuntasan belajar siswa dihitung dengan menggunakan rumus sebagai berikut:

$$
\text { Persentase siswa yang tuntas belajar }(\%)=\frac{\sum \text { Siswa yang tuntas }}{\text { Jumlah siswa }} \times 100
$$

Indikator keberhasilan dari penelitian tindakan kelas ini adalah peningkatan aktivitas belajar siswa kelas V SDN. No. 052/XI Ulu Air tahun 2016/2017 pada mata pelajaran IPA, khususnya materi sifat-sifat cahaya dari rendah menjadi baik. Selain itu, penelitian dikatakan berhasil apabila terjadi peningkatan hasil belajar siswa kelas V SDN. No. 052/XI Ulu Air tahun 2016/2017 pada mata pelajaran IPA, khususnya materi sifat-sifat cahaya yang mengacu kepada 
Kriteria Ketuntasan Minimum (KKM) kompetensi dasar yang telah ditentukan oleh sekolah di awal tahun pelajaran 2016/2017 yaitu 60,0 .

\section{HASIL DAN PEMBAHASAN Hasil Penelitian Pratindakan}

Sebelum melakukan Penelitian Tindakan Kelas, guru melakukan pengumpulan data pratindakan terlebih dahulu. Data yang dikumpulkan adalah data mengenai aktivitas siswa selama kegiatan pembelajaran IPA berlangsung. Data aktivitas belajar dikumpulkan melalui pengamatan atau observasi. Hasil pengamatan menunjukkan bahwa pelaksanaan pembelajaran masih berpusat pada guru dan cenderung kurang melibatkan siswa secara aktif. Metode yang digunakan guru adalah metode ceramah yang disertai dengan tanya jawab. Metode ini dinilai kurang tepat karena materi yang diajarkan pada mata pelajaran IPA bersifat abstrak. Penggunan metode ceramah yang disertai dengan tanya jawab berdampak pada aktivitas belajar siswa yang rendah. Karena siswa tidak dilibatkan secara aktif, siswa cenderung duduk diam di kursi masing-masing. Sebagian besar siswa juga terlihat kurang antusias dalam mengikuti kegiatan pembelajaran, tidak menyimak penjelasan guru, melamun, menguap karena mengantuk, mengobrol dengan teman sebangkunya, serta mencoret buku catatan. Dengan demikian, guru perlu mengganti metode yang digunakan dalam kegiatan pembelajaran IPA.

Guru juga mengumpulkan data hasil belajar pratindakan yang dikumpulkan melalui tes penjajakan. Tes penjajakan yang bertujuan untuk mengukur dan menilai hasil belajar siswa pada mata pelajaran IPA sebelum diberi tindakan. Hasil penelitian menunjukkan bahwa skor yang diperoleh siswa pada tes penjajakan berkisar 20,0 (skor terendah) sampai dengan 75,0 (skor tertinggi) dengan skor rata-rata sebesar 52,8. Rata-rata skor yang diperoleh siswa masih termasuk dalam kategori rendah. Jika dibandingkan dengan KKM kompetensi dasar maka diketahui bahwa hanya terdapat separuh siswa yang memperoleh skor lebih besar atau sama dengan KKM kompetensi dasar. Hasil ini diperkuat dengan capaian ketuntasan belajar siswa sebesar 50,0\%. Skor rata-rata dan persentase ketuntasan belajar yang rendah mengindikasikan bahwa tujuan pembelajaran belum tercapai. Dengan demikian, guru perlu memperbaiki proses pembelajaran. Perbaikan pada proses pembelajaran diharapkan mampu meningkatkan hasil belajar siswa yang menjadi indikator keberhasilan pembelajaran.

\section{Hasil Penelitian Siklus I}

Kegiatan penelitian pada siklus I dilaksanakan pada hari Rabu, 1 Maret 2017 (pertemuan ke-1), hari Senin, 6 Maret 2017 (pertemuan ke-2), dan hari Rabu, 8 Maret 2017 (pertemuan ke-3). Kegiatan penelitian pada siklus I terdiri atas perencanaan, pelaksanaan, pengamatan, dan refleksi.

\section{Perencanaan}

Kegiatan perencanaan terdiri atas: (1) menetapkan materi yang akan diajarkan; (2) menyusun Rencana Pelaksanaan Pembelajaran (RPP), (3) menyusun prosedur untuk melakukan percobaan; (4) melakukan uji coba pada percobaan yang akan dilaksanakan untuk menguji ketepatan proses dan hasilnya; (5) menyiapkan alat dan bahan yang dibutuhkan untuk melakukan percobaan; dan (6) menyiapkan alat evaluasi.

\section{Pelaksanaan}

Materi yang disampaikan dalam siklus I adalah sifat-sifat cahaya, yaitu cahaya merambat lurus (pertemuan ke-1 Siklus I), cahaya dapat menembus benda bening (pertemuan ke-2 Siklus I), dan cahaya dapat dipantulkan (pertemuan ke3 Siklus I). Kegiatan dilaksanakan dalam tiga tahap yaitu kegiatan awal, kegiatan inti, dan kegiatan akhir. Kegiatan awal, terdiri atas: guru mengucapkan salam dan menanyakan keadaan siswa; guru memeriksa kehadiran siswa; guru menyampaikan tujuan pembelajaran; dan guru menyampaikan skenario pembelajaran yang akan dilaksanakan. Kegiatan inti, terdiri atas: guru menjelaskan materi pembelajaran; guru menjelaskan prosedur dalam melakukan percobaan; siswa melakukan percobaan secara berkelompok; guru membantu, membimbing, dan mengawasi siswa selama kegiatan percobaan berlangsung; siswa membersihkan dan menyimpan alat dan bahan yang digunakan dalam percobaan; siswa menyusun laporan hasil percobaan; siswa menyampaikan laporan hasil percobaan di depan kelas secara bergiliran; guru memberikan kesempatan pada siswa lain untuk memberikan tanggapan; dan guru memberikan umpan balik mengenai proses dan hasil pembelajaran. Kegiatan akhir, terdiri atas: guru membimbing siswa dalam membuat simpulan pembelajaran; guru menyampaikan rencana 
pembelajaran untuk selanjutnya; dan guru menyampaikan pesan moral.

\section{Pengamatan}

Kegiatan pengamatan dilakukan dengan cara mengamati aktivitas belajar siswa selama kegiatan pembelajaran berlangsung. Hasil pengamatan menunjukkan bahwa seluruh siswa telah menyimak penjelasan yang disampaikan oleh guru, menyiapkan alat dan bahan yang dibutuhkan untuk melakukan kegiatan percobaan, bekerja bersama dengan siswa lain dalam sebuah kelompok, membersihkan kembali alat dan bahan yang digunakan dalam kegiatan percobaan, dan juga mengikuti kegiatan pembelajaran dengan antusias. Bagi siswa, penggunaan metode eksperimen dalam pembelajaran IPA merupakan sesuatu yang baru sehingga mereka antusias untuk mengikuti kegiatan pembelajaran. Selain itu, metode eksperimen memberikan kesempatan kepada siswa untuk melakukan percobaan. Metode ini mengurangi kesempatan siswa untuk melakukan aktivitas lain yang tidak berkaitan, seperti melamun, mengobrol, dan juga mencoret buku. Sebagian besar siswa juga telah melakukan kegiatan percobaan dengan mengikuti prosedur yang telah disediakan di lembar kerja siswa. Akan tetapi, masih terdapat siswa yang belum mampu melakukan percobaan karena siswa tersebut kurang memahami prosedur dalam melakukan percobaan. Dengan demikian, guru perlu membimbing dan mendampingi siswa tersebut dalam melakukan kegiatan percobaan.

Hasil pengamatan juga menunjukkan bahwa separuh siswa juga telah mampu mempresentasikan hasil percobaan di depan kelas. Hasil ini juga mengindikasikan bahwa masih ada separuh siswa yang belum berani untuk menyampaikan hasil percobaannya di depan kelas. Sebagian besar siswa juga mengalami masalah dalam hal bertanya dan menjawab pertanyaan. Sebagian besar siswa masih belum berani untuk mengajukan pertanyaan pada guru atau siswa lain dan juga menjawab pertanyaan yang diberikan oleh guru atau siswa lain. Guru perlu memberikan motivasi kepada siswa agar siswa menjadi lebih percaya diri. Guru juga perlu memberikan penguatan positif kepada siswa yang telah berani menyampaikan hasil presentasinya di depan kelas. Penguatan positif perlu dilakukan untuk mempertahankan perilaku yang diinginkan. Pemberian penguatan positif diharapkan dapat mendorong siswa untuk menjadi lebih berani lagi pada pertemuan selanjutnya.

Hasil pengamatan juga menunjukkan bahwa separuh siswa juga telah mampu membuat kesimpulan. Hasil ini juga mengindikasikan bahwa masih terdapat separuh siswa yang belum mampu membuat kesimpulan mengenai kegiatan pembelajaran. Dengan demikian, guru perlu membimbing siswa secara intensif dalam menyusun kesimpulan. Guru juga perlu memastikan seluruh siswa dapat memaknai kegiatan pembelajaran yang telah dilakukan.

Selain pengamatan, penelitian ini juga mengukur dan menilai hasil belajar siswa. Hasil belajar ini diukur di akhir siklus I yakni pada hari Senin, 13 Maret 2017. Data yang disajikan pada Tabel 4 menunjukkan bahwa skor yang diperoleh siswa pada Siklus I berada pada rentang 45,0 (skor terendah) sampai dengan 90,0 (skor tertinggi) dengan skor rata-rata sebesar 65,3. Nilai ini lebih besar dibandingkan dengan nilai rata-rata kelas saat tes penjajakan (pratindakan) yaitu 52,8. Peningkatan nilai ratarata kelas sekitar 12,5 point. Ketuntasan belajar siswa pada akhir siklus I adalah $72,2 \%$. Hasil yang diperoleh ini juga menunjukkan terjadinya peningkatan capaian ketuntasan belajar siswa dibandingkan dengan ketuntasan belajar siswa saat tes penjajakan (pratindakan) yaitu sebesar $50,0 \%$. Peningkatan yang terjadi sebesar $22,2 \%$. Berdasarkan hasil tersebut, dapat disimpulkan bahwa penggunaan metode eksperimen dalam pembelajaran dapat meningkatkan pemahaman siswa dalam mata pelajaran IPA khususnya pada konsep sifat-sifat cahaya. Hal ini terlihat dengan adanya peningkatan hasil belajar siswa yaitu setelah mengikuti kegiatan pembelajaran, siswa mampu menjelaskan tiga sifat dari cahaya, yaitu: cahaya merambat lurus, cahaya dapat menembus benda bening, dan cahaya dapat dipantulkan.

\section{Refleksi}

Hasil pengamatan menunjukkan bahwa aktivitas siswa selama kegiatan pembelajaran berangsur membaik, meskipun ada beberapa siswa masih belum mampu untuk mempresentasikan hasil percobaan, membuat kesimpulan, mengajukan pertanyaan pada guru atau siswa lain, serta menjawab pertanyaan dari guru atau siswa lain. Guru perlu memberikan motivasi dan membimbing siswa dengan lebih intensif terutama siswa yang belum terlibat aktif selama kegiatan pembelajaran Siklus I. Hasil belajar siswa yang dilihat dari nilai rata-rata dan ketuntasan belajar juga meningkat. Dengan 
demikian, penggunaan metode eksperimen perlu dilanjutkan ke Siklus II. Berdasarkan hasil Siklus I, guru merumuskan tindakan untuk siklus II.

\section{Hasil Penelitian pada Siklus II}

Kegiatan penelitian pada siklus II dilaksanakan pada hari Senin, 20 Maret 2017 dan hari Rabu, 22 Maret 2017. Kegiatan penelitian pada siklus II terdiri atas perencanaan, pelaksanaan, pengamatan, dan refleksi.

\section{Perencanaan}

Kegiatan perencanaan terdiri atas: (1) menetapkan materi yang akan diajarkan, (2) menyusun Rencana Pelaksanaan Pembelajaran (RPP), (3) menyusun prosedur untuk melakukan percobaan, (4) melakukan uji coba pada percobaan yang akan dilaksanakan untuk menguji ketepatan proses dan hasilnya, (5) menyiapkan alat dan bahan yang dibutuhkan untuk melakukan percobaan, dan menyiapkan alat evaluasi.

\section{Pelaksanaan}

Materi yang disampaikan dalam siklus II adalah sifat-sifat cahaya, yaitu cahaya dapat dibiaskan (pertemuan ke-1 Siklus II) dan cahaya dapat diuraikan (pertemuan ke-2 Siklus II). Kegiatan dilaksanakan dalam tiga tahap yaitu kegiatan awal, kegiatan inti, dan kegiatan akhir. Kegiatan awal, terdiri atas: Guru mengucapkan salam dan menanyakan keadaan siswa; Guru memeriksa kehadiran siswa; Guru menyampaikan tujuan pembelajaran; Guru menyampaikan skenario pembelajaran yang akan dilaksanakan; Kegiatan inti, terdiri atas: guru menjelaskan materi pembelajaran; guru menjelaskan prosedur dalam melakukan percobaan; siswa melakukan percobaan secara berkelompok; guru membantu, membimbing, dan mengawasi siswa selama kegiatan percobaan berlangsung; siswa membersihkan dan menyimpan alat dan bahan yang digunakan dalam percobaan; siswa menyusun laporan hasil percobaan; siswa menyampaikan laporan hasil percobaan di depan kelas secara bergiliran; guru memberikan kesempatan pada siswa lain untuk memberikan tanggapan; dan guru memberikan umpan balik mengenai proses dan hasil pembelajaran. Kegiatan akhir, terdiri atas: guru membimbing siswa dalam membuat simpulan pembelajaran; guru menyampaikan rencana pembelajaran untuk selanjutnya; dan guru menyampaikan pesan moral.

\section{Pengamatan}

Hasil pengamatan menunjukkan bahwa seluruh siswa telah menyimak penjelasan yang disampaikan oleh guru, menyiapkan alat dan bahan yang dibutuhkan untuk melakukan kegiatan percobaan, bekerja bersama dengan siswa lain dalam sebuah kelompok, membaca prosedur untuk melakukan kegiatan percobaan, melakukan kegiatan percobaan sesuai dengan prosedur percobaan, membersihkan kembali alat dan bahan yang digunakan dalam kegiatan percobaan, dan juga mengikuti kegiatan pembelajaran dengan antusias. Hasil ini menggambarkan bahwa penggunaan metode eksperimen dalam pembelajaran IPA meningkatkan semangat siswa untuk mengikuti kegiatan pembelajaran. Peningkatan semangat ini mendorong siswa untuk terlibat aktif dalam kegiatan pembelajaran, seperti mendengar penjelasan guru, menyiapkan alat dan bahan yang dibutuhkan, bekerja secara berkelompok, membaca prosedur dengan teliti sebelum melakukan kegiatan percobaan, dan juga membersihkan kembali alat dan bahan yang digunakan dalam kegiatan percobaan. Sebagian besar siswa juga telah mampu untuk menulis hasil percobaan.

Hasil pengamatan juga menunjukkan bahwa sebagian besar siswa juga telah mampu untuk mempresentasikan hasil percobaan di depan kelas, mengajukan pertanyaan pada guru atau siswa lain, dan menjawab pertanyaan dari guru atau siswa lain. Meskipun demikian, masih ditemukan juga siswa yang belum mampu untuk mempresentasikan hasil percobaan di depan kelas, mengajukan pertanyaan pada guru atau siswa lain, dan menjawab pertanyaan dari guru atau siswa lain. Hal ini disebabkan oleh siswa kurang berani menyampaikan pendapatnya di hadapan guru dan siswa lain. Guru perlu memberikan motivasi kepada siswa agar siswa menjadi lebih percaya diri. Guru juga perlu memberikan penguatan positif kepada siswa yang telah berani menyampaikan hasil presentasinya di depan kelas. Penguatan positif perlu dilakukan untuk mempertahankan perilaku yang diinginkan. Pemberian penguatan positif diharapkan dapat mendorong siswa untuk menjadi lebih berani lagi pada pertemuan selanjutnya.

Kemampuan siswa dalam membuat kesimpulan juga meningkat. Hasil pengamatan juga menunjukkan bahwa tujuh dari sepuluh siswa telah mampu membuat kesimpulan. Hasil ini juga mengindikasikan bahwa masih terdapat 
$30,0 \%$ siswa yang belum mampu membuat kesimpulan mengenai kegiatan pembelajaran. Dengan demikian, guru perlu membimbing siswa secara intensif dalam menyusun kesimpulan.

Selain pengamatan, penelitian ini juga mengukur dan menilai hasil belajar siswa. Hasil belajar ini diukur di akhir siklus II yakni pada hari Senin, 27 Maret 2017. Hasil pengukuran dan penilaian hasil belajar siswa Siklus II menunjukkan bahwa skor yang diperoleh siswa pada evaluasi Siklus II berkisar 55,0 (skor terendah) sampai dengan 100,0 (skor tertinggi) dengan skor rata-rata sebesar 75,3. Nilai ini lebih besar dibandingkan dengan nilai rata-rata kelas saat tes penjajakan (pratindakan) yaitu 52,8 dan evaluasi siklus I yaitu 65,3. Peningkatan nilai rata-rata kelas sekitar 12,2 point jika dibandingkan dengan hasil evaluasi Siklus I dan 24,3 point jika dibandingkan dengan hasil tes penjajakan. Hasil penelitian juga menunjukkan bahwa ketuntasan belajar siswa pada akhir siklus II adalah $88,9 \%$. Hasil yang diperoleh ini juga menunjukkan terjadinya peningkatan capaian ketuntasan belajar siswa dibandingkan dengan ketuntasan belajar siswa saat tes penjajakan (pratindakan) yaitu sebesar $50,0 \%$ dan siklus I sebesar $72,2 \%$. Peningkatan yang terjadi sekitar $16,7 \%$ jika dibandingkan dengan hasil evaluasi Siklus I dan 38,9\% jika dibandingkan dengan hasil tes penjajakan. Berdasarkan hasil tersebut, dapat disimpulkan bahwa penggunaan metode eksperimen dalam pemebelajaran IPA dapat meningkatkan hasil belajar siswa dalam mata pelajaran IPA khususnya pada konsep sifat-sifat cahaya. Setelah mengikuti kegiatan pembelajaran dengan metode eksperimen, siswa mampu menjelaskan tiga sifat dari cahaya, yaitu: cahaya dapat dibiaskan dan cahaya dapat diuraikan.

\section{Refleksi}

Mengingat tindakan siklus II telah mengalami kemajuan yang cukup signifikan, baik berdasarkan aktivitas siswa maupun berdasarkan hasil belajar maka peneliti memutuskan untuk menghentikan tindakan pada siklus II. Dengan demikian, penelitian tindakan kelas dianggap selesai.

\section{Pembahasan}

Hasil pengamatan menunjukkan bahwa pelaksanaan pembelajaran sebelum diberikan tindakan masih berpusat pada guru dan cenderung kurang melibatkan siswa secara aktif.
Metode yang digunakan guru adalah metode ceramah yang disertai dengan tanya jawab. Metode ini dinilai kurang tepat karena materi yang diajarkan pada mata pelajaran IPA bersifat abstrak. Penggunan metode ceramah yang disertai dengan tanya jawab berdampak pada aktivitas belajar siswa yang rendah. Karena siswa tidak dilibatkan secara aktif, siswa cenderung duduk diam di kursi masing-masing. Sebagian besar siswa juga terlihat kurang antusias dalam mengikuti kegiatan pembelajaran, tidak menyimak penjelasan guru, melamun, menguap karena mengantuk, mengobrol dengan teman sebangkunya, serta mencoret buku catatan.

Pemberian tindakan yaitu penerapan metode eksperimen pada mata pelajaran IPA membawa pengaruh baik bagi aktivitas belajar siswa. Dengan menerapkan metode eksperimen, seluruh siswa telah menyimak penjelasan yang disampaikan oleh guru, menyiapkan alat dan bahan yang dibutuhkan untuk melakukan kegiatan percobaan, bekerja bersama dengan siswa lain dalam sebuah kelompok, membaca prosedur untuk melakukan kegiatan percobaan, melakukan kegiatan percobaan sesuai dengan prosedur percobaan, membersihkan kembali alat dan bahan yang digunakan dalam kegiatan percobaan, dan juga mengikuti kegiatan pembelajaran dengan antusias. Sebagian besar siswa juga telah mampu untuk menulis hasil percobaan, membuat kesimpulan, mempresentasikan hasil percobaan di depan kelas, mengajukan pertanyaan pada guru atau siswa lain, dan menjawab pertanyaan dari guru atau siswa lain.

Hasil penelitian menunjukkan bahwa metode eksperimen juga dapat meningkatkan aktivitas belajar siswa kelas V SDN. No. 052/XI Ulu Air tahun 2016/2017 pada mata pelajaran IPA, khususnya pada materi sifat-sifat cahaya. Hasil ini mendukung pernyataan Rusman (2011) bahwa pembelajaran akan lebih bermakna jika siswa diberi kesempatan untuk berpartisipasi dalam berbagai aktivitas kegiatan pembelajaran, sehingga siswa mampu mengaktualisasikan kemampuannya di dalam dan di luar kelas. Dengan demikian, metode pembelajaran yang sebaiknya digunakan leh guru adalah metode pembelajaran yang berpusat pada siswa.

Selain aktivitas belajar, penelitian ini juga mengukur dan menilai hasil belajar siswa. Hasil belajar siswa dilihat dari nilai rata-rata kelas dan ketuntasan belajar siswa. Rekapitulasi hasil belajar siswa pada saat pratindakan, siklus I, dan siklus II disajikan pada Gambar 1. 


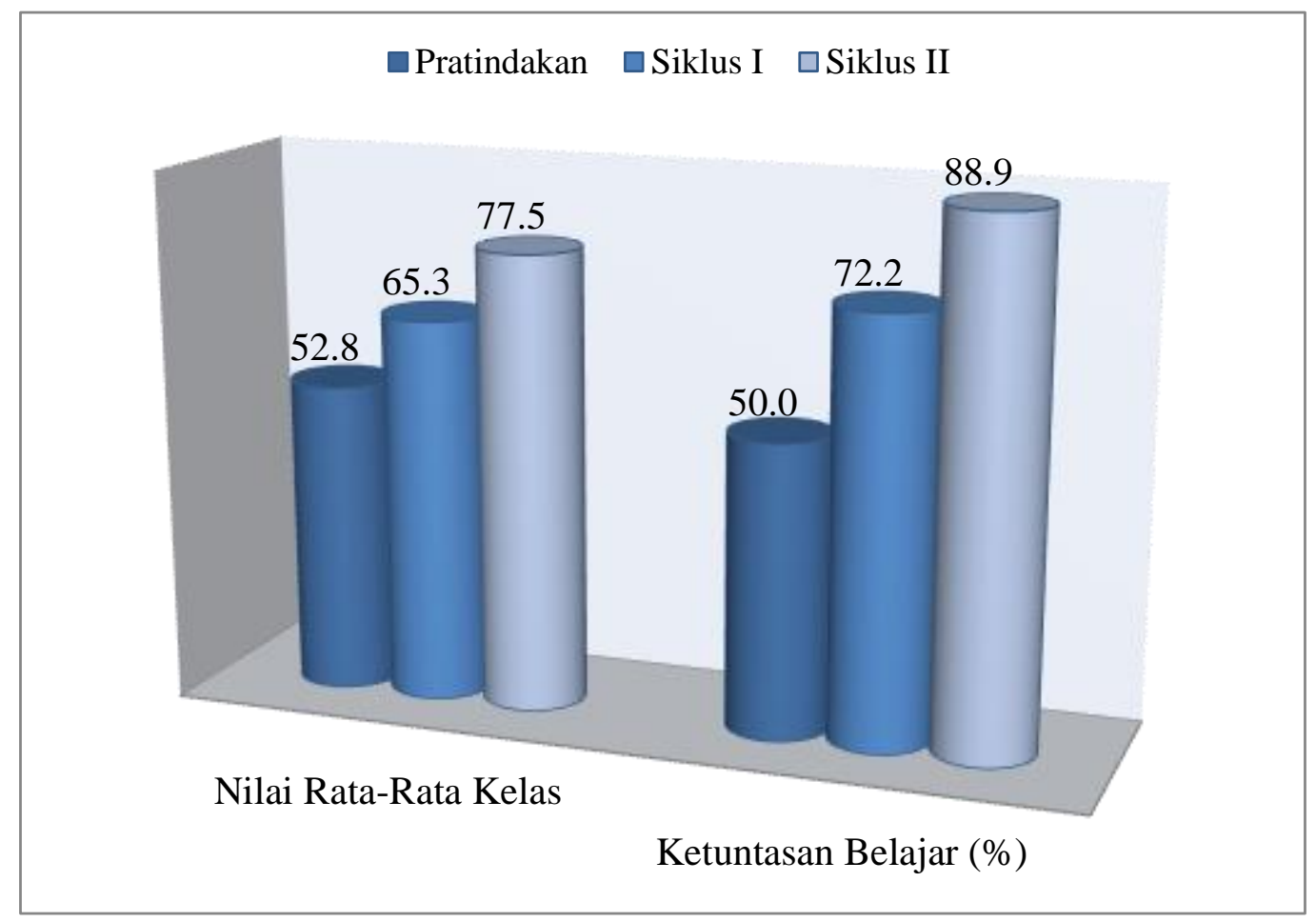

Gambar 1 Rekapitulasi hasil belajar siswa pada saat pratindakan, siklus I, dan siklus II

Hasil penelitian yang disajikan pada Gambar 1 memperlihatkan bahwa nilai rata-rata kelas yang pada saat pratindakan hanya sebesar 52,8 meningkat menjadi 65,0 pada akhir siklus I dan kembali meningkat menjadi 75,3 pada akhir siklus II. Apabila hasil pada akhir siklus II dibandingkan dengan hasil pada saat pratindakan maka diperoleh selisih sebesar 22,5 point. Selain peningkatan nilai rata-rata kelas, ketuntasan belajar siswa juga meningkat. Ketuntasan belajar siswa pada saat pratindakan hanya sebesar $50,0 \%$ meningkat menjadi $72,2 \%$ pada akhir siklus I dan kembali meningkat menjadi $88,9 \%$ pada akhir siklus II. Apabila hasil pada akhir siklus II dibandingkan dengan hasil pada saat pratindakan maka diperoleh selisih sebesar $38,9 \%$.

Hasil penelitian menunjukkan bahwa terjadi peningkatan hasil belajar siswa dari sebelum dilaksanakan tindakan sampai dengan setelah dilaksanakan tindakan (siklus I dan siklus II). Berdasarkan hasil penelitian, dapat disimpulkan bahwa penggunaan metode eksperimen berhasil meningkatkan hasil belajar siswa pada mata pelajaran IPA, khususnya pada materi sifat-sifat cahaya. Hasil yang diperoleh ini menguatkan hasil penelitian yang telah dilakukan sebelumnya bahwa penggunaan metode eksperimen dapat meningkatkan hasil belajar siswa pada mata pelajaran IPA, khususnya pada materi sifat-sifat cahaya
(Basonggo, Tangkas, dan Said, 2014; Yesnain, Ratman, dan Gagaramusu, 2015; Munawar, 2016; Suarni, Haeruddin, dan Dewi, 2016). Hasil penelitian ini menguatkan temuan Basonggo, Tangkas, dan Said (2014) yang menyatakan bahwa metode eksperimen dapat meningkatkan hasil belajar siswa dalam pembelajaran IPA di Kelas V SDN Meselesek. Hasil penelitian ini juga menguatkan hasil penelitian Yesnain, Ratman, dan Gagaramusu (2015) bahwa penggunaan metode eksperimen dapat meningkatkan hasil belajar siswa tentang sifat cahaya pada pembelajaran IPA di Kelas V SDN Lalampu. Hasil penelitian ini juga menguatkan temuan Munawar (2016) bahwa penggunaan metode eksperimen dapat meningkatkan hasil belajar siswa pada materi sifat-sifat cahaya melalui pada kelas V SD Inpres 2 Lontio. Hasil penelitian ini juga mendukung temuan Suarni, Haeruddin, dan Dewi (2016) bahwa penerapan metode eksperimen dapat meningkatkan hasil belajar siswa kelas V SDN 1 Balukang pada mata pelajaran IPA materi sifat-sifat cahaya.

Hasil belajar siswa mencerminkan kemampuan siswa dalam memahami konsep atau materi yang telah diajarkan. Peningkatan hasil belajar siswa mengindikasikan bahwa tingkat pemahaman siswa mengenai materi juga semakin meningkat. Peningkatan hasil belajar dapat diartikan juga sebagai peningkatan kemampuan siswa dalam memahami 
konsep/materi. Pemahaman siswa mengenai materi akan membantu siswa dalam menjawab tes yang diberikan. Kemampuan siswa menjawab tes dengan benar dapat meningkatkan hasil belajar siswa. Hasil penelitian ini menguatkan bahwa metode pembelajaran berperan penting dalam keberhasilan pembelajaran. Hal ini dapat terjadi karena penggunaan metode eksperimen dalam kegiatan pembelajaran berpengaruh terhadap prestasi belajar siswa. Temuan Yogantara, Murda, dan Rati (2014) telah membuktikan bahwa metode eksperimen memberikan pengaruh yang signifikan terhadap prestasi belajar siswa Sekolah Dasar pada mata pelajaran IPA. Dengan demikian, metode eksperimen dapat menjadi salah satu alternatif bagi guru untuk meningkatkan hasil belajar siswa pada mata pelajaran IPA khususnya pada materi sifat-sifat cahaya.

\section{SIMPULAN}

Penerapan metode eksperimen pada mata pelajaran IPA membawa pengaruh baik bagi aktivitas belajar siswa. Dengan menerapkan metode eksperimen, aktivitas belajar siswa menjadi semakin baik. Hasil pengamatan menunjukkan seluruh siswa telah menyimak penjelasan yang disampaikan oleh guru, menyiapkan alat dan bahan yang dibutuhkan untuk melakukan kegiatan percobaan, bekerja bersama dengan siswa lain dalam sebuah kelompok, membaca prosedur untuk melakukan kegiatan percobaan, melakukan kegiatan percobaan sesuai dengan prosedur percobaan, membersihkan kembali alat dan bahan yang digunakan dalam kegiatan percobaan, dan juga mengikuti kegiatan pembelajaran dengan antusias. Sebagian besar siswa juga telah mampu untuk menulis hasil percobaan, membuat kesimpulan, mempresentasikan hasil percobaan di depan kelas, mengajukan pertanyaan pada guru atau siswa lain, dan menjawab pertanyaan dari guru atau siswa lain.

Penerapan metode eksperimen pada mata pelajaran IPA juga membawa pengaruh baik bagi hasil belajar siswa. Setelah pemberian tindakan (Siklus I dan Siklus II), Hasil belajar siswa yang dilihat dari nilai rata-rata kelas dan ketuntasan belajar mengalami peningkatan dibandingkan dengan nilai rata-rata kelas dan ketuntasan belajar saat pratindakan. Penerapan metode eksperimen memudahkan siswa dalam memahami mengenai sifat-sifat cahaya. Pemahaman mengenai materi juga sangat membantu siswa dalam menjawab soal tes yang menjadi alat ukur dari hasil belajar. Dengan demikian, metode eksperimen dapat meningkatkan aktivitas dan hasil belajar siswa kelas V SDN. No. 052/XI Ulu Air tahun 2016/2017 pada mata pelajaran IPA, khususnya pada materi sifat-sifat cahaya.

\section{DAFTAR PUSTAKA}

Andriyanto, A., Mokoginta, D, \& Saleh, M. (2013). Meningkatkan hasil belajar siswa pada materi sifat-sifat cahaya melalui metode demonstrasi di kelas V SDN 5 Telaga Kecamatan Telaga Kabupaten Gorontalo. Jurnal Penelitian Tindakan Kelas, 1(1), hlm. 1-14.

Basonggo, I., Tangkas, I. M., \& Said, I. (2014). Meningkatkan Hasil Belajar Siswa Melalui Metode Eksperimen dalam Pembelajaran IPA di Kelas V SDN Meselesek. Jurnal Kreatif Tadulako Online, 2(2), hlm. 96-104.

Irham, M., \& Wiyani, N. A. (2013). Psikologi Pendidikan: Teori dan Aplikasi dalam Proses Pembelajaran. Yogyakarta: Ar Ruzz Media.

Munawar. 2016. Meningkatkan Hasil Belajar Siswa Pada Materi Sifat-Sifat Cahaya Melalui Penggunaan Metode Eksperimen Pada Kelas V SD Inpres 2 Lontio. Jurnal Kreatif Tadulako Online, 4(12), hlm. 8191.

Novera, E. (2012). Meningkatkan kemampuan mengenal sifat cahaya melalui metode demonstrasi bagi anak tuna rungu di SLB Negeri Ampek Angkek, dalam EJUPEKhu (Jurnal Ilmiah Pendidikan Khusus), 1(3), hlm. 264-272.

Suarni, Haeruddin, \& Dewi, A.I. (2016). Penerapan Metode Eksperimen pada Materi Sifat Cahaya Pada Mata Pelajaran IPA Kelas V SDN 1 Balukang Untuk Meningkatkan Hasil Belajar Siswa. Jurnal Kreatif Tadulako Online, 4(1), hlm. 170182.

Sugihartono, dkk. (2007). Psikologi Pendidikan. Yogyakarta: UNY Press.

Suprihatiningrum, J. (2014). Strategi Pembelajaran: Teori dan Aplikasi. Yogyakarta: Ar Ruzz Media.

Yesnain, Ratman, \& Gagaramusu, Y. (2015). Meningkatkan Hasil Belajar Siswa dengan Menggunakan Metode Eksperimen Sifat Cahaya pada Pembelajaran IPA di Kelas 
V. Jurnal Kreatif Tadulako Online, 3(1), hlm. 53-66.

Yogantara, G. N. B., Murda, I. N., \& Rati, N. W.

(2014). Pengaruh Metode Eksperimen terhadap Prestasi Belajar IPA Siswa Kelas IV SD Negeri Gugus IV Kabupaten

Buleleng. e-Journal MIMBAR PGSD

Universitas Pendidikan Ganesha, 2(1). 